increased to $28 \mathrm{C}$, seedling width and number of leaves increased (Table 2). The mean number of days to visible bud increased as temperature increased to $31 \mathrm{C}$. These results indicated that higher temperatures resulted in larger transplants. However, the production of larger transplants would be of little value commercially since many of the large transplants did not flower on schedule.

In summary, the results of both experiments support the hypothesis that high temperature exposure of lisianthus seedlings causes development of rosetted and semirosetted plants. The percentage of rosetted plants increased as the duration of exposure to $28 \mathrm{C}$ soil increased from 0 to 28 days and as soil temperature increased from 22 to $31 \mathrm{C}$. Cultivars varied in their sensitivity to high temperatures during the seedling stage. The pink cultivars were the most sensitive in both experiments, with $34 \%$ rosetted plants for 'USDA-Pink' at the lowest temperature of 22C. The cultivar GCREC-Blue was selected for heat tolerance from a tissue cultured line of 'Blue Poppy' at the Gulf Coast Research and Education Center. The low tendency to form rosetted plants by 'GCRECBlue' at high temperature exposure (2\% rosetted plants with $31 \mathrm{C}$ soil for 28 days) indicates that breeding efforts can reduce the high temperature sensitivity in lisianthus.

\section{Literature Cited}

Bailey, L.H. and E.Z. Baily. 1976. Hortus Third. MacMillan, New York.

Halevy, A.H. and A.M. Kofranek. 1984. Evaluation of lisianthus as a new flower crop. HortScience 19:845-847.
Harbaugh, B.K. 1988. Scheduling lisianthus (Eustoma grandiflorum) production. Gulf Coast Res. and Educ. Ctr. Res. Rpt. BRA1988-25.

Little, T.M. and F.J. Hills. 1975. Statistical methods in agricultural research. Univ. of California Press, Davis.

Ohkawa, K., A. Kano, K. Kanematsu, and M. Korenaga. 1991. Effects of air temperature and time on rosette formation in seedlings of Eustoma grandiflorum (Raf.) Shinn. Scientia Hort. 48:171-176.

Roh, M.S., A.H. Halevy, and H.F. Wins. 1989 Eustoma grandiflorum, p, 322-327. In: A.H. Halevy (ed.). Handbook of flowering. vol. VI. Crit. Rev. Plant Sci. Nutr. Press, Boca Raton, Fla.

Roh, M.S. and R.H. Lawson. 1987. Research and development on new crops in the United States Department of Agriculture. Acta Hort. 205:3948

\title{
Role of Self-pollination and Reciprocal Stigma/Anthers Position on Fruit Set of Eight Self-compatible Almonds
}

\author{
A. Godini, L. de Palma, and M. Palasciano \\ Istituto di Coltivazioni Arboree, Università di Bari, 70126 Bari, Italy \\ Additional index words. Amygdalus communis, Prunus dulcis, Apulian almonds, hand \\ self-pollination, flower morphology, self-fruitfulness
}

\begin{abstract}
A bstract. A study to ascertain the highest possible fruit set following self-pollination of eight self-compatible cultivars of almond (A mygdalus communis $L$. = P runus dulcis $M$ ill) was carried out in Apulia (southern Italy). F ruits set from daily hand-selling were high, compared to those from unassisted self-pollination. The results support growing most of the self-compatible A pulian almonds in solid blocks, without need for cross-pollination, provided that self-pollination is optimized by insect vectors. The relative capability of the cultivars to set fruits by unassisted self-pollination was independent of the reciprocal stigma/anthers position within the same flower.
\end{abstract}

About 30 sweet and bitter almond cultivars native to Apulia (southern Italy) have been identified as self-compatible. Their fruit set after natural self-pollination averaged $<15 \%$ and never $>26 \%$ (Godini, 1977b; Godini et al., 1990a; Reina et al., 1985). Since $25 \%$ to $40 \%$ fruit set is considered optimal for almond, depending on the bloom density of the cultivar (Kester and Griggs, 1959a), the fruitfulness of Apulian self-compatible almonds by natural self-pollination is biologically interesting but horticulturally inadequate.

Two studies on the effect of natural and

Received for publication 8 July 1991, Accepted for publication 18 Feb. 1992. Research funded by the Ministero Agricoltura e Foreste (Italy), special Grant ISMEZ (Paper no. 386). We are grateful to V. D'Alessandro and P. Simeone for their invaluable cooperation in field trials. The cost of publishing this paper was defrayed in part by the payment of page charges. Under postal regulations, this paper therefore must be hereby marked advertisement solely to indicate this fact. artificial selfing on the fruit set of single selfcompatible almond cultivars have been completed. The first study, undertaken in Greece, demonstrated the capability of the Apulian cv. Truoito (syn. "Tuono") to exceed the optimal fruit set by both artificial and natural selfing of flowers (Vasilakakis and Porlingis, 1984). These successful results have been attributed to the intimate stigma/anther contact within single 'Truoito' flowers, which facilitates the natural transfer of pollen grains to the stigmatic surface. The second study was conducted in the United States on 'Le Grand, derived from peach-almond interspecific hybridization and possessing a flower morphology similar to that of 'Truoito' (Weinbaum, 1985). 'Le Grand' was incap able of achieving optimal fruit set using either artificial and natural selfing of flowers.

Given the different results of the above studies and the few genotypes concerned, further documentation involving a wider range of self-compatible almond cultivars seemed necessary. Therefore, we conducted a study to determine if self-pollination may allow selffruitful almond cultivars to bear sufficient crops to be planted in solid blocks i) without provision for cross-pollination (Kester and Asay, 1975) and/or ii) without insect vectors (Weinbaum, 1985). To answer these questions, the capability of eight Apulian selfcompatible almond cultivars to reach optimal fruit set after artificial and natural self-pollination was tested in 1990 at Valenzano (Apulia, Italy).

Cross-pollination was prevented by covering single mature trees throughout bloom with insect-proof cheesecloth cages, thus eliminating any possible injury to flowers by branch-bagging (Grasselly and Olivier, 1976). A single tree was chosen for each cultivar. On each tree, 20 flowering branches, each bearing 80 to 120 blossoms, were divided

Table 1. Bloom date and duration, number of hand self-pollinations, and weather conditions throughout the pollination period of Apulian almonds.

\begin{tabular}{|c|c|c|c|c|c|c|}
\hline \multirow[b]{2}{*}{ Cultivar } & \multicolumn{2}{|c|}{ Bloom } & \multirow{2}{*}{$\begin{array}{l}\text { Hand self- } \\
\text { pollination } \\
\text { (no.) }\end{array}$} & \multirow{2}{*}{$\begin{array}{l}\text { Mean daily } \\
\text { air temp } \\
\left({ }^{\circ} \mathrm{C}\right)\end{array}$} & \multirow[b]{2}{*}{$\begin{array}{c}\text { Rainfall } \\
\text { (mm) }\end{array}$} & \multirow{2}{*}{$\begin{array}{l}\text { Avg wind } \\
\text { speed } \\
\left(\mathrm{m} \cdot \mathrm{s}^{-1}\right)\end{array}$} \\
\hline & Date & $\begin{array}{l}\text { Duration } \\
\text { (days) }\end{array}$ & & & & \\
\hline Sannicandro & 6-21 Feb. & 16 & 14 & 10.2 & 8.4 & 1.3 \\
\hline Scorza verde & 6-24 Feb. & 19 & 17 & 10.4 & 8.4 & 1.2 \\
\hline Ferrante & 7-24 Feb. & 18 & 16 & 10.5 & 8.4 & 1.3 \\
\hline Filippo Ceo & 15-23 Feb. & 9 & 9 & 12.0 & 0.0 & 1.0 \\
\hline Patalina & 19 Feb.-1 Mar. & 11 & 11 & 13.1 & 0.0 & 1.2 \\
\hline Tuono & 19 Feb.-1 Mar. & 11 & 11 & 13.1 & 0.0 & 1.2 \\
\hline Calò & $21-28$ Feb. & 8 & 8 & 13.0 & 0.0 & 1.0 \\
\hline Genco & 21 Feb.-1 Mar. & 9 & 9 & 13.5 & 0.0 & 1.2 \\
\hline
\end{tabular}


Table 2. Fruit set of hand and unassisted self-pollinated flowers and spatial position of stigma and anthers of Apulian almonds.

\begin{tabular}{|c|c|c|c|c|}
\hline \multirow[b]{2}{*}{ Cultivar } & \multicolumn{2}{|c|}{$\begin{array}{l}\text { Fruit set following } \\
\text { self-pollination }\end{array}$} & \multirow[b]{2}{*}{ Significance } & \multirow{2}{*}{$\begin{array}{c}\text { Distance of stigma } \\
\text { from highest } \\
\text { anther } \\
( \pm \mathrm{mm} \pm \mathrm{SE})\end{array}$} \\
\hline & $\begin{array}{c}\text { By hand } \\
(\%)\end{array}$ & $\begin{array}{l}\text { Unassisted } \\
(\%)\end{array}$ & & \\
\hline Sannicandro & 40.8 & 8.7 & ** & $3.48 \pm 0.33 \mathrm{~cd}^{2}$ \\
\hline Scorza verde & 44.4 & 19.1 & ** & $-0.47 \pm 0.35 \mathrm{e}$ \\
\hline Ferrante & 14.3 & 2.8 & NS & $-0.19 \pm 0.34 \mathrm{e}$ \\
\hline Filippo Ceo & 46.5 & 8.5 & $* *$ & $6.61 \pm 0.38 \mathrm{a}$ \\
\hline Patalina & 28.0 & 2.3 & ** & $2.55 \pm 0.30 \mathrm{~d}$ \\
\hline Tuono & 33.5 & 18.0 & * & $0.20 \pm 0.30 \mathrm{~d}$ \\
\hline Cald & 67.0 & 18.7 & ** & $5.42 \pm 0.53 \mathrm{~b}$ \\
\hline Genco & 62.5 & 4.8 & ** & $3.88 \pm 0.23 c$ \\
\hline Mean & 42.1 & 10.4 & ** & \\
\hline $\mathrm{cv}(\%)$ & 25.2 & 61.3 & & \\
\hline
\end{tabular}

${ }^{2}$ Mean separation by Duncan's multiple range test, $P=0.01$.

Ns $*$, **Nonsignificant or significant at $P=0.05$ or 0.01 , respectively. Significance tested by ANOVA of arcsin-transformed fruit sets, then backtransformed from Arcsin.

into two groups of $\approx 1000$ flowers each. The flowers of the first group of 10 branches were artificially selfed daily from the start to the end of bloom by rubbing stigmas with a small bristle brush carrying self pollen. The method used mimics insect vectors' activity and assumes that $100 \%$ of counted flowers were effectively self-pollinated at least once during their effective pollination period (Kester and Griggs, 1959a). The pollen for selfing was harvested every 3rd day from the same tree under study. Repeated viability testing with aceto-carmine indicated $\approx 90 \%$ live pollen. The flowers of the second group of 10 branches were left to naturally self-pollinate by wind buffeting of branches (unassisted self-pollination).

The distance from stigma to the highest anther was measured on samples of 30 flowers per cultivar to test the role of reciprocal stigma/anthers position on fruit set following unassisted selfing. Measurements were taken $24 \mathrm{~h}$ after flowers had opened, when at least one to five anthers were dehiscing, so as to make it possible for the pollen to be naturally transferred to the stigmatic papillae of the same flower.

Weather conditions were recorded. Hand self-pollinations were made late in the morning, except on rainy and/or windy days. The cages were removed after petal fall. The data are reported as final fruit set, calculated in mid-July, 2 months after the end of physiological fruit drop in almond (Kester and Griggs, 1959b).

The bloom period of the eight cultivars lasted from 6 Feb.-1 Mar. (Table 1). The average air temperature throughout bloom was $12 \mathrm{C}$, ranging from 1 to $27 \mathrm{C}$. Total rainfall was $8.4 \mathrm{~mm}$, and average wind speed was $1.2 \mathrm{~m} \cdot \mathrm{s}^{-1}$. Weather conditions were favorable for pollen germination, pollen tube growth, and fertilization.

Hand self-pollination allowed very high average fruit set (Table 2), which in many cultivars exceeded the levels reported as optimal for almond. Unassisted selfing proved inadequate, and none of the cultivars tested reached $20 \%$ fruit set. The higher coefficient of variation indicates that the setting ability of the unassisted selfed flowers was some- what more erratic than that of hand-selfed ones. Hand-selfing increased the average fruit set by four times compared with unassisted selfing. The increase in fruit set of handselfed cultivars ranged from 1.9 times ('Tuono') to 13.0 times ('Genco'). Handselfing was ineffective only in 'Ferrante', which behaved like 'Le Grand' (Weinbaum, 1985), thus confirming its partial self-compatibility (Godini et al., 1990b). The distance of stigmas from the highest anther was essentially constant within the same cultivar but varied significantly among cultivars (Table 2). 'Scorza Verde', 'Ferrante', and 'Tuono' exhibited mesostigmatic flowers, whereas 'Sannicandro', 'Filippo Ceo', 'Patalina', 'Calb', and 'Genco' exhibited epistigmatic flowers. Since no correlation was found between stigma/anthers position and fruit set obtained by unassisted selfing, it may be erroneous to attribute a biological significance to the noted morphological characteristics of almond flowers.

Wind buffeting of unbagged flowering branches alone was inadequate to ensure sufficient pollination to support optimum fruit set (Weinbaum, 1985). Therefore, the role of intimate contact of the pollen grains with the stigmatic surface appears to be critical to produce a satisfactory fruit set (Westvood et al., 1966). Because of the high bloom density of Apulian almond ecotypes (Grasselly and Crossa Raynaud, 1980), all cultivars tested, except 'Ferrante', proved sufficiently self-fertile to produce a full crop, but only when self-pollination was artificially optimized. Our results on fruit set induced by unassisted selling agree with those of Weinbaum (1985) and disagree with those of Vasilakakis and Porlingis (1984). We suggest that Vasilakakis and Porlingis (1984) used a particularly fertile clone of 'Truoito'. In fact, in our past investigations (Godini, 1977b; Godini et al., 1990b; Reina et al., 1985) and in the present study, none of the 30 self-compatible Apulian cultivars, including 'Tuono', approached the unusually high fruit sets after natural selfing shown by 'Truoito' in Greece.

Our data indicate that most of the selfcompatible Apulian almonds tested can be grown in solid blocks without the need for cross-pollination, provided that adequate insect vectors are available to ensure optimum self-pollination. The availability of selfcompatible almond cultivars can be interpreted as a step toward overcoming some of the problems of almond orchard management due to self-incompatibility (Tufts, 1919). We point out that Apulian almond growers ignore the relationship between pollinating intensity and fruit set (Kester and Griggs, 1959a) and continue to entrust the pollen transfer to wild insect vectors. Because of the scarcity of the wild vector populations, pollen transfer and fruit sets are generally low. Under such conditions, self-compatible almond cultivars set consistently more heavily (two times and more) than self-incompatible ones (Godini, 1977a). The comparatively higher and more consistent yield is the main reason for the interest in some self-fertile Apulian almond cultivars by growers and scientists in the Mediterranean basin. 'Genco' and 'Tuono' are increasingly planted in commercial orchards and are being used as parents in breeding programs to introduce self-compatibility into the genome of self-incompatible cultivars native to France (Grasselly, 1985), Spain (Felipe and Socias i Company, 1988) and Tunisia (El Gharbi, 1980).

\section{Literature Cited}

El Gharbi, A. 1980. Résultats préliminaires des croisements intervarietaux d'amandier réalisés en Tunisie. Options Médit., IAMZ/1:23-25.

Felipe, A. and R. Socias i. Company. 1988. Trois variétés autocompatibles d'amandier provenant d'une programme de selection et d'amélioration. 7th GREMPA Meeting, Reus, Spain, EUR 11557:9-16.

Godini, A. 1977a. Un quadriennio di ricerche sulle cause della improduttività dei mandorleti baresi. 3rd GREMPA Meeting, BARI, Italy. p. 67-86

Godini, A. 1977b. Contributo alla conoscenza delle cultivar di mandorlo della Puglia: 2) un quadriennio di ricerche sulla autocompatibilita. 3rd GREMPA Meeting, Bari, Italy. p. 203-207.

Godini, A., L. de Palma, and M. Palasciano. 1990a. Sur l'autocompatibilitt des amandiers amers des Pouilles. 8th GREMPA Meetine. Nimes (France). (In press.)

Godini, A., L. de Palma, and M. Palasciano. 1990b. Effect of optimized self-pollination on fruit set of self-compatible almond cultivars. XXIII Intl. Hort. Congr. Florence. Italy. Poster no. 3197.

Grasselly, C. 1985. Avancement du programme "autocompatibilité" chez l'amandier. Options Médit., IAMZ/1:39-41

Grasselly, C. and P. Crossa Raynaud. 1980. L'amandier. Maisonneuve et Larose, Paris.

Grasselly, C. and G. Olivier. 1976. Mise in evidence de quelques types autocompatibles parm les cultivars d'amandier ( $P$. amygdalus Batsch) de la population des Pouilles. Ann. Amélior: Plantes 26:107-113.

Kester, D.E. and R. Asay. 1975. Almonds, p. 387-419. In: J. Janick and J.N. Moore (eds.). Advances in fruit breeding. Purdue Univ. Press, West Lafayette, Ind.

Kester, D.E. and W.H. Griggs. 1959a. Fruit setting in the almond: The effect of cross-pollinating various percentages of flowers. Proc. 
Amer. Soc. Hort. Sci. 74:206-213.

Kester, D.E. and W.H. Griggs. 1959b. Fruit setting in the almond: The pattern of flower and fruit drop. Proc. Amer. Soc. Hort. Sci. 74:214219.

Reina, A., V. Giorgio, and A. Godini. 1985. Autres types autocompatibles parmi la population d'a- mandiers des Pouilles. Options Medit., IAMZ 1:25-29.

Tufts, W.P. 1919. Almond pollination. Calif. Agr. Sta. Bul. 306.

Vasilakakis, M.D. and I.C. Porlingis. 1984. Selfcompatibility in 'Truoito' almond and effect of temperature on selfed and crossed pollen tube growth. HortScience 19:659-661.

Weinbaum, S.A. 1985. Role of natural self-pollination in self-fruitfulness of almond. Scientia Hart. 27:295-302.

Westwood, M.M., W.P. Stephen, and C.B. Cordy. 1966. The possibility of wind pollination in pear. HortScience 1:28-29.

\section{Defoliation of Strawberry Transplants for Fruit Production in Florida}

\author{
E.E. Albregts, C.M. Howard, and C.K. Chandler \\ Agricultural Research and Education Center, University of Florida, \\ I3138 Lewis Gallagher Road, Dover, FL 33527
}

\section{Additional index words Fragaria $\times$ ananassa}

\begin{abstract}
Florida-developed strawberry (Fragaria xananassa Duch.) clones or varieties grown in Florida nurseries and California-developed varieties grown in Canadian nurseries were evaluated in fruiting studies in Florida during four seasons. Transplants were defoliated so that $0 \%, 35 \%, 60 \%$, or $87 \%$ of the foliage was removed. The Florida clones 'Dover' and selection 79-1126 gave significant linear and/or quadratic early and total marketable yield responses to defoliation treatments for all seasons. The Canadian-grown clones 'Chandler' and 'Selva' gave similar responses during three seasons, but differences were not as great as for the Florida-grown clones. Many significant linear and quadratic responses in seasonal average fruit weight and plant size occurred for Florida-grown plants, but only one occurred with the Canadian-grown plants. Relative plant size at early and midseason decreased with greater defoliation.
\end{abstract}

Strawberry transplants used in the annual hill cultural system in Florida are produced locally for clones developed in Florida, while clones developed in California are generally produced in nurseries in the northern United States or southern Canada. The reasons for this are 2-fold. California clones grown in northern areas are less susceptible to anthracnose (Colletotrichum spp.) (a devastating disease in Florida) in the nursery and fruiting field than the same clones grown in Florida (Howard and Albregts, 1982). In addition, because of plant chilling and the shorter daylengths in the northern nurseries, plants stored in the roots when shipped to Florida (Bringhurst et al., 1960). Florida-developed plants flower 4 to 8 weeks later than the same plants from northern U.S. nurseries. Since Florida-developed plants are mostly plants is generally done in Florida because of lower costs. Locally produced plants are transplanted with foliage intact, since defoliation of these plants has been found to cause plant mortality and fruiting problems (Albregts and Howard, 1972). Regardless of origin, transplants are usually irrigated with overhead sprinklers during the daytime stress

Received for publication 23 Sept. 1991. Accepted for publication 18 Mar. 1992. Florida Agricultural Experiment Station Journal Series no. R-01842. The cost of publishing this paper was defrayed in part by the payment of page charges. Under postal regulations, this paper therefore must be hereby marked advertisement solely to indicate this fact. have flower buds in the crown and starch resistant to anthracnose, production of trans- period until established to reduce foliage loss. Irrigation for establishment could be reduced by as much as $50 \%$ and shipping costs would also be less if Canadian-grown plants could be defoliated before shipping or if Floridagrown plants could be partially defoliated before planting. With reduced foliage, foliage diseases and mites (Tetranychus urticae Koch) would have a lower probability of being transferred to the fruiting field, which might lower pesticide usage. However, for economic reasons, fruit production should not be delayed or reduced by defoliation.

The purpose of this study was to determine the effect of various amounts of defoliation on the plant growth and fruiting response of Florida- and Canadian-grown nursery plants.

Studies were conducted at Agricultural Research and Education Center (AREC), Dover, during four winter (October through April) seasons, 1987-88 through 1990-91, using the annual hill cultural system. The soil was a Seffner fine sand (sandy, siliceous, hyperthermic Quartzipsammentic Haplumbrepts). Transplants of 'Dover' and breeding line FL-79-1126 were produced at AREC-Dover, and 'Chandler' and 'Selva' transplants were produced in southern Ontario. 'Chandler' and 'Selva' transplants were not produced in Florida because of the problem with anthracnose as noted above. Raised beds were fertilized with $224 \mathrm{~N}-20 \mathrm{P}-184 \mathrm{~K}$ (kg-ha-r), fumigated with a $98 \%$ methylbromide and $2 \%$ chloropicrin mixture at 448 kg-ha-' of bed area and mulched with black polyethylene. Transplants were set on 27 Oct. 1987, 20 Oct. 1988 and 1989, and 22 Oct. 1990, with two rows per bed and plants spaced $30 \mathrm{~cm}$ between and $28 \mathrm{~cm}$ within rows. Overhead sprinkler irrigation and labeled pesticides were applied as needed. Defoliation treatments of plants consisted of measuring the height of the foliage and removing
Table 1. Early marketable fruit yields of strawberry (through January) during four seasons as affected by foliage removal and plant source.

\begin{tabular}{|c|c|c|c|c|c|}
\hline \multirow[b]{2}{*}{ Plant source } & \multirow{2}{*}{$\begin{array}{c}\text { Foliage } \\
\text { removed } \\
(\%)\end{array}$} & \multicolumn{4}{|c|}{ Early marketable fruit yield $\left(\mathrm{Mg}^{\prime} \mathrm{ha}^{-1}\right)^{\mathbf{z}}$} \\
\hline & & $1987-88$ & $1988-89$ & $1989-90$ & $1990-91$ \\
\hline Floriday & $\begin{array}{r}87 \\
60 \\
35 \\
0\end{array}$ & $1.4 \mathrm{~b}$ & $\begin{array}{r}4.1 \\
8.1 \\
9.3 \\
10.9\end{array}$ & $\begin{array}{l}1.7 \\
5.0 \\
5.6 \\
5.1\end{array}$ & $\begin{array}{l}2.9 \\
4.1 \\
5.7 \\
7.7\end{array}$ \\
\hline Significance & & & & & \\
\hline $\begin{array}{l}\text { Treatment } \\
\text { Linear } \\
\text { Ouadratic }\end{array}$ & & $*$ & $\begin{array}{l}* * * \\
* * * \\
*\end{array}$ & $\begin{array}{l}* * \\
* * * \\
* * *\end{array}$ & $* * *$ \\
\hline Canada & $\begin{array}{r}87 \\
60 \\
0\end{array}$ & $\begin{array}{l}4.6 \\
4.6\end{array}$ & $\begin{array}{r}6.5 \mathrm{~b} \\
10.3 \mathrm{a}\end{array}$ & $\begin{array}{l}4.6 \mathrm{~b} \\
4.6 \mathrm{~b}^{\mathrm{x}} \\
6.2 \mathrm{a}\end{array}$ & $\begin{array}{l}5.3 \\
6.3 \\
8.4\end{array}$ \\
\hline $\begin{array}{c}\text { Significance } \\
\text { Treatment } \\
\text { Linear } \\
\text { Quadratic }\end{array}$ & & NS & ** & $*$ & $\begin{array}{l}* * * \\
* * * \\
\text { NS }\end{array}$ \\
\hline
\end{tabular}

${ }^{2}$ Megagrams $/ 2.78=$ yield/plot in kilograms.

"1987-88 data are only for Florida-grown FL-79-1126, and 1987-88 and 1988-89 data are only for Canadian-grown 'Chandler'. All other data are averages of two clones.

"Defoliated $87 \% 2$ weeks before plant harvest.

Ns ****,***Nonsignificant or significant at $P=0.05,0.01$, or 0.001 , respectively, using ANOVA $\mathrm{F}$ test (treatment) and regressions. 